\title{
HUBUNGAN TINGKAT PENGETAHUAN PENGELOLA OBAT TERHADAP PENGELOLAAN OBAT DI PUSKESMAS
}

\author{
CORRELATION BETWEEN DRUGS MANAGER KNOWLEDGE LEVEL AND THEIR DRUGS MANAGEMENT \\ ABILITY AT PUBLIC HEALTH
}

\begin{abstract}
Alyxia Fatma Aryani, Anjar Mahardian Kusuma, Githa Fungie Galistiani
Fakultas Farmasi, Universitas Muhammadiyah Purwokerto
\end{abstract}

ABSTRAK

\begin{abstract}
Pada tahun 2011 di seluruh puskesmas di Indonesia menunjukkan bahwa hanya 17,5\% puskesmas di Indonesia yang memiliki apoteker dan ada sekitar 32,2\% puskesmas yang tidak memiliki tenaga kefarmasian sama sekali. Penelitian ini bertujuan untuk mengetahui tingkat pengetahuan pengelola unit farmasi di puskesmas, mengetahui bagaimana pengelolaan obat yang dilakukan oleh pengelola unit farmasi yang ada di puskesmas, mengetahui ada tidaknya hubungan antara tingkat pengetahuan pengelola unit farmasi dengan kemampuannya mengelola obat di puskesmas.Penelitian ini merupakan penelitian observasional analitik melalui pendekatan cross sectional. Kuisioner digunakan untuk mengukur tingkat pengetahuan dan daftar ceklis untuk mengukur pengelolaan obat. Peneliti melakukan Penelitian di Puskesmas Kabupaten Banyumas dengan jumlah responden 37 responden. Data dianalisis menggunakan uji statstik spearman rank. Hasil penelitian menunjukkan nilai $p$ value sebesar 0,031 yang menunjukkan ada hubungan antara tingkat pengetahuan pengelola unit farmasi terhadap pengelolaan obat di Puskesmas Kabupaten Banyumas. Nilai Coefficient Correlation 0,355 yang menunjukkan kekuatan dan arah penelitian yang bersifat searah yang jika tingkat pengetahuan tinggi maka pengelolaan obat akan tinggi pula.
\end{abstract}

Kata Kunci: Pengelolaan Obat, Tingkat Pengetahuan, Kemampuan, Puskesmas

\section{ABSTRACT}

In 2011 all health centers in Indonesia showed that only $17.5 \%$ of puskesmas in Indonesia which has a pharmacist and there are about $32.2 \%$ of health centers do not have at all pharmacy personnel.. This study aims to determine the level of knowledge of the pharmaceutical unit manager at the health center, find out how the drug management by the management unit of pharmaceuticals in health centers, determine whether there is a correlation between the level of knowledge of the pharmaceutical unit manager with the ability to administer the drug in puskesmas. This is an observational study cross sectional analytic approach. A questionnaire was used to measure the level of knowledge and a list of checklist to measure medication management. Researchers conducted the study in Banyumas district health center by the number of respondents 37 respondents. Analyzed data using the Spearman rank test statstik. The results showed $p$ value of 0.031 which indicates there is a correlation between the level of knowledge of the pharmaceutical unit manager for the management of drugs in health centers Banyumas. 0.355 Correlation Coefficient value that indicates the strength and direction of research that is the direction that if a high level of knowledge, the management of the drug will be higher as well.

Keywords: Drugs Management, Knowledge Level, Ability, Health Centers

\section{PENDAHULUAN}

Obat merupakan komponen utama yang sangat mempengaruhi dalam pelayanan kesehatan khususnya dalam bidang kefarmasian. Obat adalah bahan atau paduan dari beberapa bahan-bahan kimia yang digunakan untuk mengobati atau memperbaiki sistem fisiologi atau keadaan patologi dalam rangka penetapan diagnosis, pencegahan, penyembuhan, pemulihan, peningkatan kesehatan. Pengelolaan obat sendiri menurut penelitian yang dilakukan oleh Suryawati dan

\section{Korespondensi}

Alyxia Fatma Aryani

Fakultas Farmasi, Universitas Purwokerto Jl. Raya Dukuhwaluh

Email : alyxiafatmaa@gmail.com
Anisa pada tahun 2005 menyebutkan bahwa pengelolaan obat terdiri dari beberapa unsur yang saling berkaitan satu sama lain yaitu: perencanaan, permintaan, penerimaan, penyimpanan, distribusi, pengendalian penggunaan serta pencatatan dan pelaporan. Berdasarkan penelitian tersebut menyebutkan bahwa permintaan obat khususnya untuk puskesmas dilakukan oleh petugas pengelola obat tetapi dengan sepengetahuan kepala puskesmas. Pentingnya pengelola obat yang merupakan seorang apoteker adalah kunci utamanya. Hal ini di dukung oleh PP no 51 tahun 2009 tentang Pekerjaan Kefarmasian diperkenankan untuk melakukan penyediaan obat adalah tenaga apoteker.

Untuk di Indonesia sendiri pengelolaan obat yang dilakukan oleh pengelola obat 
khususnya pada puskesmas masih tergolong kurang baik ini dibuktikan dengan penelitian yang dilakukan oleh Suryawati dan anisa pada tahun 2005 yang melakukan penelitian di 4 kabupaten yaitu Sleman, Banyumas, Kulon Progo dan Kudus sebagian besar penggunaan obat yang dilakukan di 4 kabupaten tersebut menggunakan obat dengan nama dagang sehingga terjadi peningkatan biaya obat pada tiap resep, serta peningkatan obat non esensial dan peningkatan penggunaan antibiotik pada masyarakat. Berdasarkan penelitian tersebut hal ini disebabkan karena di puskesmas lebih kurang $50 \%$ tenaga pengelola obatnya tidak memiliki latar belakang pendidikan farmasi. Menurut Herman et al., (2011) menyebutkan bahwa puskesmas yang memiliki apoteker sebagai pengelola obatnya memiliki kualitas pelayanan yang lebih baik dari pada puskesmas yang hanya memiliki ttk sebagai pengelola obatnya. Pada tahun 2011 di seluruh Puskesmas di Indonesia menunjukkan bahwa hanya 17,5\% puskesmas di Indonesia yang memiliki apoteker dan ada sekitar 32,2\% puskesmas yang tidak memiliki tenaga kefarmasian sama sekali. Berdasarkan hasil penelitian tersebut juga dikatakan bahwa apoteker berperan lebih baik dalam memberikan pelayanan farmasi, mengelola obat dan menyusun Lembar Pemakaian dan Lembar Permintaan Obat (LPLPO) dengan lengkap dibandingkan dengan tenaga teknis kefarmasian dan tenaga teknis kefarmasian juga berperan lebih baik dibandingkan dengan tenaga non-farmasi dalam hal yang sama. (Herman, 2013).

Berdasarkan profil tenaga kefarmasian provinsi yang ada di Indonesia provinsi jawa tengah memiliki puskesmas sebanyak 861 unit, yang mana hanya $16,1 \%$ saja puskesmas yang memiliki apoteker dan hanya $65,6 \%$ saja yang mempunyai tenaga teknis farmasi sisanya sebanyak 18,2\% Puskesmas tidak ada apoteker ataupun tenaga teknis kefarmasian sama sekali. Pada Kabupaten Banyumas sendiri memiliki 39 unit puskesmas dengan Puskesmas Rawat Inap sebanyak 14 unit dan Puskesmas Non Rawat Inap sebanyak 25 unit (Dinkes Provinsi, 2014). Berdasarkan jumlah tenaga kefarmasian yang ada untuk wilayah Kabupaten Banyumas terdapat 8 orang tenaga farmasi dan 10 orang asisten farmasi yang bekerja di Puskesmas seKabupaten Banyumas (Dinkes Provinsi, 2014).

Kurangnya tenaga apoteker dan pentingnya pengetahuan yang dimiliki oleh tenaga kefarmasian mendorong saya untuk melakukan penelitian untuk mengetahui ada tidaknya hubungan antara tingkat pengetahuan pengelola obat dengan kemampuannya mengelola obat di puskesmas yang ada di Kabupaten Banyumas.Mengacu kepada hasil penelitian tahun 2005 terdapat hubungan yang bermakna antara faktor pendidikan dengan kinerja pengelolaan obat di Puskesmas. Ini berbanding lurus (Aziz, 2006) salah satu upaya untuk meningkatkan tingkat pengetahuan petugas Puskesmas adalah dengan melakukan pelatihan. Oleh sebab itu peneliti tertarik untuk melakukan penelitian untuk mengetahui ada tidaknya hubungan antara tingkat pengetahuan pengelola unit farmasi terhadap kemampuannya mengelola obat di Puskesmas Kabupaten Banyumas. Adapun tujuan dilakukannya penelitian ini adalah untuk mengetahui tingkat pengetahuan pengelola unit farmasi di Puskesmas, mengetahui pengelolaan obat yang dilakukan oleh pengelola unit farmasi yang ada di Puskesmas, serta mengetahui ada tidaknya hubungan antara tingkat pengetahuan pengelola unit farmasi dengan kemampuannya mengelola obat di Puskesmas.

\section{METODE}

Penelitian ini merupakan penelitian observasional analitik yang akan mengetahui ada tidaknya hubungan antara tingkat pengetahuan pengelola unit farmasi dengan kemampuan mengelola obat pada unit instalasi farmasi di Puskesmas yang berada di wilayah Kabupaten Banyumas. Penelitian ini melalui pendekatan cross sectional. Penelitian dilakukan pada bulan April-Juni tahun 2016 cara pengumpulan data melalui observasi yang dilakukan di unit pelayanan farmasi di Puskesmas menggunakan daftar pertanyaan berupa kuisioner kepada petugas yang bertanggung jawab terhadap pengelolaan obat di Puskesmas Kabupaten Banyumas dan juga menggunakan daftar ceklis yang dibuat peneliti 
untuk memastikan kemampuan pengelolaan obat pada instalasi farmasi di Puskesmas wilayah Kabupaten Banyumas.

Sampel dalam penelitian ini adalah seluruh pengelola obat dii nstalasi farmasi di Puskesmas Kabupaten Banyumas dengan total 39 orang. Teknik penyamplingan yang saya gunakan adalah total sampling. Alasan digunakan teknik ini adalah untuk memperkecil bias yang mungkin terjadi selama melakukan penelitian.

Validasi menggunakan rumus Korelasi Pearson product moment. pengujian reliabilitas dengan teknik Alpha dilakukan untuk jenis data angket atau bentuk uraian. Karna data yang digunakan dalam bentuk uraian maka pengujian dilakukan dengan menggunakan teknik alpha. Normality Test. Sebelum dilakukan analisis statistik, terlebih dahulu dilakukan uji kenormalan dengan menggunakan normality test. Karena sampel yang digunakan $\leq 50$ sampel, maka menggunakan uji Shapiro-Wilk. Variabel yang ada di dalam penelitian ini diduga memiliki hubungan adalah tingkat pengetahuan dengan kemampuan mengelola obat pada unit farmasi di Puskesmas Kabupaten Banyumas. Analisis dilakukan dengan menggunakan uji Spearman karena data yang digunakan berskala ordinal.

\section{HASIL DAN PEMBAHASAN}

\section{Uji Validitas dan Reliabilitas}

Uji validitas dilakukan dengan menggunakan "koefisien biseral" dengan bentuk pertanyaan objektif dengan skor 0 dan 1 . Hasil dari uji validitas menunjukkan bahwa 42 item pertanyaan tersebut memiliki $r$ hitung yang lebih besar dari $\mathrm{r}$ tabel maka dapat dinyatakan bahwa kuisioner tersebut $100 \%$ valid dengan $r$ hitung lebih besar dari $\mathrm{r}$ tabel berkisar 0,458 0,701 . $r$ tabel untuk uji validitas ini sebesar 0,433 yang dengan $r$ tabel ini disebabkan karena dalam penyusunan item item pernyataan di kuisioner pernyataan favorable dan unfavorable tidak di acak secara merata yang menyebabkan data bisa menjadi bias pada saat melakukan penelitian yang sebenarnya.

Uji reliabilitas dilakukan pada 42 butir pertanyaan pengetahuan tentang pengelolaan obat di Puskesmas secara umum dengan menggunakan rumus Cronbach's Alpha dengan ketentuan bahwa suatu butir pertanyaan mempunyai reliabilitas jika nilai Cronbach's Alpha positif dan juga Nilai Cronbach's Alpha hasil perhitungan sama atau lebih besar dari 0,8 atau nilai Cronbach's Alpha harus lebih besar dari ambang bawah yaitu antara 0,6-0,7 (Sarwono, 2015). Dari uji reliabilitas nilai Cronbah's Alpha yang diperoleh untuk pengetahuan pengelolaan obat di Puskesmas sebesar 0,943 . Sehingga instrumen dinyatakan reliabel karena menurut sarwono (2015) nilai Cronbach Alpha harus sama atau lebih besar dari 0,8 .

\section{Karakteristik Responden}

Berdasarkan Tabel I, pengelola obat yang mempunyai pendidikan terakhir profesi apoteker paling dominan yaitu sebanyak 30 orang yang menempuh pendidikan terakhir apoteker, 5 orang menempuh pendidikan D3 farmasi, dan 1 orang D3 perawat. Dan dapat diketahui bahwa status pekerjaan pekerja kontrak sebanyak 22 orang lebih dominan daripada pekerja PNS sebanyak 15 orang. Dominannya pengelola obat yang berjenis kelamin perempuan sebanyak 27 orang dibandingkan laki-laki sebanyak 10 orang pada Tabel I, memiliki hubungan dengan kinerja seorang pekerja. Pegawai perempuan cenderung lebih cekatan dan teliti dibandingkan pekerja laki-laki. Faktor ketelitian dan kualitas pelayanan akan meningkat seiring dengan semakin baiknya kinerja pekerja (Tabel I).

Ini sejalan dengan penelitian yang dilakukan Wahyudi (2002) yang mengatakan bahwa penilaian kinerja adalah suatu evaluasi yang dilakukan secara periodik dan sistematik tentang prestasi/jabatan seseorang. Jabatan seseorang atau status pekerjaan mempengaruhi kinerja seseorang yang memiliki hubungan terhadap motivasi untuk bekerja dengan gaji yang didapat dan beban yang diterima. Selain itu Katajavuori, et al., (2009) mengatakan bahwa kualitas pendidikan kefarmasian harus memperhatikan kurikulum pembelajaran. Sejalan dengan hasil penelitian yang dilakukan oleh A, et al., (2002), menunjukkan adanya hubungan tingkat pendidikan dengan 
Tabel I. Karakteristik Responden

\begin{tabular}{lccc}
\hline & & \multicolumn{2}{c}{ Responden } \\
& $\begin{array}{c}\text { Apoteker }(\mathrm{f}=31) \\
\mathrm{n}(\%)\end{array}$ & $\begin{array}{c}\text { D3 Farmasi }(\mathrm{f}=5) \\
\mathrm{n}(\%)\end{array}$ & $\begin{array}{c}\text { D3 Perawat }(\mathrm{f}=1) \\
\mathrm{n}(\%)\end{array}$ \\
\cline { 3 - 4 } & & & \\
Usia & $15(40,54)$ & $1(2,70)$ & 0 \\
$<28$ tahun & $16(43,24)$ & $4(10,81)$ & $1(2,70)$ \\
$\geq 28$ tahun & & & \\
Status Pekerjaan & $9(24,32)$ & $4(10,81)$ & $1(2,70)$ \\
PNS & $21(56,75)$ & $1(2,70)$ & 0 \\
Kontrak & & & 0 \\
Pendidikan Terakhir & $30(81,08)$ & 0 & 0 \\
Profesi Apoteker & 0 & $5(13,51)$ & $1(2,70)$ \\
D3 Farmasi & 0 & 0 & $1(2,70)$ \\
D3 Perawat & & & 0 \\
Jenis Kelamin & $20(54,05)$ & $5(13,51)$ & \\
Perempuan & $10(27,02)$ & 0 & \\
Laki-laki & & & \\
& & &
\end{tabular}

kemampuan pengelolaan obat. Tingkat farmasi dalam pengelolaan obat di puskesmas semakin tinggi tingkat pendidikan pengelola obat yang berpendidikan farmasi AA lebih tinggi dari pada yang berlatar pendidikan non pendidikan seseorang maka sebanding dengan pengetahuan yang dimilikinya.

\section{Pengetahuan Pengelolaan Obat}

Pengetahuan adalah segala sesuatu yang diketahui mengenai hal sesuatu, pengetahuan merupakan hasil dari tau. Pengkategorian tingkat pengetahuan peneliti mengacu pada buku Biostatistika oleh Budiarto (2002) tentang rentang (range) peneliti menggunakan 2 nilai yaitu nilai terendah dan nilai tertinggi. Selanjutnya, peneliti mencari deviasi antara nilai terbesar dan nilai terkecil kemudian membaginya menjadi 3 karena peneliti ingin membagi menjadi 3 kategori yakni kategori tinggi,sedang, dan rendah. Lalu didapatkan range sebesar 3,67 selanjutnya peneliti menentukan nilai untuk masing-masing kategori. Pertama untuk tingkat pengetahuan dengan kategori rendah responden harus memperoleh skor antara 31-34,67, untuk tingkat pengetahuan dengan kategori sedang responden harus memperoleh skor antara 34,6838,34 , dan tingkat pengetahuan untuk kategori tinggi responden harus memperoleh skor antara 38,35-42.

Tingkat pengetahuan pengelola obat diukur dengan 7 aspek yaitu perencanaan, permintaan, penerimaan, penyimpanan, distribusi, pengendalian serta pencatatan dan pelaporan (Table II-VII).

Berdasarkan hasil pengamatan dari 7 aspek di atas didapatkan hasil (Tabel IX) sebanyak 19 pengelola unit farmasi memiliki pengetahuan tinggi yaitu 15 orang apoteker, 3 orang lulusan D3 farmasi, dan 1 orang lulusan D3 perawat. Sebanyak 13 pengelola unit farmasi memiliki pengetahuan sedang diantaranya adalah 12 orang apoteker dan 1 orang lulusan D3 farmasi. Sedangkan untuk pengelola unit farmasi yang memiliki pengetahuan rendah sebanyak 5 pengelola obat 4 diantaranya merupakan apoteker dan 1 diantaranya merupakan lulusan D3 farmasi.

Ini dikarenakan oleh berbagai faktor (Tabel I) pengelola unit farmasi yang memiliki umur $>28$ tahun lebih dominan daripada $<28$ tahun yang menyebabkan pengetahuan lebih tinggi karena semakin bertambahnya usia akan semakin meningkatkan pengalaman. Kurangnya pengalaman serta masa kerja yang terhitung kurang dari 2 tahun 
Tabel II. Pengetahuan tentang Perencanaan Obat di Puskesmas Kabupaten Banyumas

\begin{tabular}{ccc}
\hline Skor yang diperoleh & \multicolumn{2}{c}{ Pengelola Unit Farmasi } \\
\cline { 2 - 3 } pengelola unit farmasi & Apoteker $(\mathbf{f}=\mathbf{3 1}) \mathbf{n}(\mathbf{\%})$ & Non Apoteker $(\mathbf{f}=\mathbf{6}) \mathbf{n}(\mathbf{\%})$ \\
\hline 6 & $14(37,8)$ & $3(8,1)$ \\
5 & $10(27,0)$ & $2(5,4)$ \\
4 & $4(10,8)$ & 0 \\
3 & $3(8,1)$ & $1(2,7)$ \\
& Skor Maksimal $=6$ & \\
\hline
\end{tabular}

TabelII. Pengetahuan tentang Permintaan Obat di Puskesmas Kabupaten Banyumas

\begin{tabular}{ccc}
\hline Skor yang diperoleh & \multicolumn{2}{c}{ Pengelola Unit Farmasi } \\
\cline { 2 - 3 } pengelola unit farmasi & Apoteker (f=31) $\mathbf{n}(\%)$ & Non Apoteker (f=6) $\mathbf{n}(\%)$ \\
\hline 2 & $26(70,3)$ & $4(10,8)$ \\
1 & $3(8,1)$ & $2(5,4)$ \\
0 & $2(5,4)$ & 0 \\
& Skor Maksimal =2 & \\
\hline
\end{tabular}

Tabel IV. Pengetahuan tentang Penerimaan Obat di Puskesmas Kabupaten Banyumas

\begin{tabular}{ccc}
\hline Skor yang diperoleh & \multicolumn{2}{c}{ Pengelola Unit Farmasi } \\
\cline { 2 - 3 } pengelola unit farmasi & Apoteker $(\mathbf{f}=\mathbf{3 1}) \mathrm{n}(\%)$ & Non Apoteker $(\mathbf{f}=\mathbf{6}) \mathrm{n}(\%)$ \\
\hline 7 & $16(43,2)$ & $5(13,5)$ \\
6 & $10(27,0)$ & $1(2,7)$ \\
5 & $4(10,8)$ & 0 \\
4 & $1(2,7)$ & 0 \\
& Skor Maksimal $=7$ & \\
\hline
\end{tabular}

Tabel V. Pengetahuan tentang Penyimpanan Obat di Puskesmas Kabupaten Banyumas

\begin{tabular}{ccc}
\hline Skor yang diperoleh & \multicolumn{2}{c}{ Pengelola Unit Farmasi } \\
\cline { 2 - 3 } pengelola unit farmasi & Apoteker $(\mathbf{f}=\mathbf{3 1}) \mathbf{n}(\mathbf{\%})$ & Non Apoteker $(\mathbf{f}=\mathbf{6}) \mathbf{n}(\%)$ \\
\hline 12 & $7(18,9)$ & $3(8,1)$ \\
11 & $12(32,4)$ & $1(2,7)$ \\
10 & $5(13,5)$ & $1(2,7)$ \\
9 & $6(16,2)$ & $1(2,7)$ \\
8 & $1(2,7)$ & 0 \\
& Skor Maksimal =12 & \\
\hline
\end{tabular}

Tabel VI. Pengetahuan tentang Pendistribusian Obat di Puskesmas Kabupaten Banyumas

\begin{tabular}{ccc}
\hline Skor yang diperoleh & \multicolumn{2}{c}{ Pengelola Unit Farmasi } \\
\cline { 2 - 3 } pengelola unit farmasi & Apoteker $(\mathrm{f}=31) \mathrm{n}(\%)$ & Non Apoteker $(\mathrm{f}=6) \mathrm{n}(\%)$ \\
\hline 3 & $20(54,1)$ & $3(8,1)$ \\
2 & $9(24,3)$ & $3(8,1)$ \\
1 & $2(5,4)$ & 0 \\
& Skor Maksimal $=3$ & \\
\hline
\end{tabular}


Tabel VII. Pengetahuan tentang Pengendalian Obat di Puskesmas Kabupaten Banyumas

\begin{tabular}{ccc}
\hline Skor yang diperoleh pengelola unit & \multicolumn{2}{c}{ Pengelola Unit Farmasi } \\
\cline { 2 - 3 } farmasi & Apoteker $(\mathrm{f}=31) \mathrm{n}(\%)$ & Non Apoteker $(\mathrm{f}=6) \mathrm{n}(\%)$ \\
\hline 5 & $25(67,6)$ & $5(13,5)$ \\
4 & $6(16,2)$ & $1(2,7)$ \\
& Skor Maksimal = 5 & \\
\hline
\end{tabular}

Tabel VIII. Pengetahuan tentang Pencatatan,Pelaporan, dan Arsip di Puskesmas Kabupaten Banyumas

\begin{tabular}{ccc}
\hline \multirow{2}{*}{$\begin{array}{c}\text { Skor yang diperoleh pengelola unit } \\
\text { farmasi }\end{array}$} & \multicolumn{2}{c}{ Pengelola Unit Farmasi } \\
\cline { 2 - 3 } & Apoteker $(\mathrm{f}=31) \mathrm{n}(\%)$ & Non Apoteker $(\mathrm{f}=6) \mathrm{n}(\%)$ \\
\hline 3 & $25(67,6)$ & $5(13,5)$ \\
2 & $6(16,2)$ & $1(2,7)$ \\
& Skor Maksimal $=3$ & \\
\hline
\end{tabular}

menjadi faktor utama yang menyebabkan tingkat pengetahuan pengelola unit farmasi tersebut tidak memiliki perbedaan. Ini sejalan dengan penelitian yang dilakukan oleh Margaretta (2014) Pengetahuan petugas pengelola obat dipengaruhi oleh 2 faktor yaitu masa kerja atau pengalaman kerja serta lingkungan kerja. Pengetahuan dapat diperoleh melalui pengalaman, pengalaman dapat diperoleh apabila seseorang telah melakukan pekerjaan secara rutin dan terus menerus. Semakin lama masa kerja seseorang dan melakukan pekerjaan secara berulang maka akan menyebabkan orang tersebut akan memiliki keterampilan yang lebih dibandingkan dengan orang yang memiliki masa kerja yang relative singkat.

\section{Pengelolaan Obat}

Pengukuran kemampuan pengelolaan obat menggunakan instrumen penelitian berupa daftar checklist. Untuk penilaian kemampuan petugas pengelola obat di unit farmasi peneliti menggunakan 5 indikator yaitu, kesesuaian item obat yang tersedia dengan DOEN, kesesuaian ketersediaan obat dengan pola penyakit, presentase obat yang tidak diresepkan, presentase penulisan obat generik, dan presentase obat kadaluarsa atau rusak.

\section{Hasil Pengamatan (Tabel III)}

Penilaian kemampuan pengelolaan obat dibagi menjadi 3 kategori yaitu Sangat Mampu
(SM), Mampu (M), dan Kurang Mampu (KM). Untuk pembagian ketiga kategori tersebut didasarkan pada pertimbangan peneliti yang membagi 5 indikator sehingga didaptkan 3 kategori, untuk kategori sangat mampu pengelola obat harus memenuhi $>3$ indikator, untuk kategori mampu pengelola obat harus memenuhi 3 indikator, untuk kategori kurang mampu pengelola obat memenuhi $<3$ indikator. Berdasarkan hasil pengamatan pada (Tabel III) diketahui bahwa sebanyak $56,75 \%$ atau sebanyak 21 pengelola unit farmasi di 21 Puskesmas di Kabupaten Banyumas sangat mampu melakukan pengelolaan obat, sebanyak $37,83 \%$ atau 14 pengelola unit farmasi di Puskesmas Kabupaten Banyumas mampu melakukan pengelolaan obat dan sebanyak $5,40 \%$ atau sejumlah 2 pengelola unit farmasi di Puskesmas Kabupaten Banyumas kurang mampu melakukan pengelolaan obat.

Dapat disimpulkan bahwa 35 Puskesmas yang ada di Kabupaten Banyumas telah mampu melakukan pengelolaan obat dengan baik dan sudah sesuai dengan standar pelayanan kefarmasian di Puskesmas. Sementara 2 Puskesmas yang pengelola unit farmasi kurang mampu melakukan pengelolaan obat di Puskesmas dipengaruhi oleh kurangnya motivasi yang dimiliki oleh pengelola unit farmasi, beban kerja yang diberikan terlalu berat, serta kurangnya tenaga kefarmasian yang 
Tabel IX. Tingkat Pengetahuan Pengelola Unit Farmasi tentang Pengelolaan Obat di Puskesmas Kabupaten Banyumas

\begin{tabular}{lcc}
\hline \multirow{2}{*}{ Kategori Pengetahuan } & \multicolumn{2}{c}{ Pengelola Unit Farmasi } \\
\cline { 2 - 3 } & Apoteker (f=31) & Non Apoteker (f=6) \\
\hline Tinggi & $15(40,5)$ & $4(10,8)$ \\
Sedang & $12(32,4)$ & $1(2,7)$ \\
Rendah & $4(10,8)$ & $1(2,7)$ \\
\hline
\end{tabular}

Tabel X. Kemampuan Pengelolaan Obat oleh Pengelola Unit Farmasi di Puskesmas Kabupaten Banyumas

\begin{tabular}{lcc}
\hline \multirow{2}{*}{ Kategori Kemampuan Pengelolaan Obat } & \multicolumn{2}{c}{ Pengelola Unit Farmasi } \\
\cline { 2 - 3 } & Apoteker $(\mathbf{f}=\mathbf{3 1})$ & Non Apoteker $(\mathbf{f}=\mathbf{6})$ \\
\hline Sangat Mampu & $16(43,2)$ & $5(13,5)$ \\
Mampu & $13(35,1)$ & $1(2,7)$ \\
Kurang Mampu & $2(5,4)$ & 0 \\
\hline
\end{tabular}

Tabel XI. Hubungan tingkat pengetahuan dengan pengelolaan obat di Puskesmas Kabupaten Banyumas

\begin{tabular}{lcc}
\hline \multirow{2}{*}{ Variabel } & \multicolumn{2}{c}{ Hasil Analisis } \\
\cline { 2 - 3 } & Correlation Coefficient & p value \\
\hline Tingkat Pengetahuan Pengelolaan Obat & 0,355 & 0,031 \\
\hline
\end{tabular}

ikut membantu pelayanan kefarmasian di Puskesmas. Menurut penelitian yang dilakukan Hall TL dan Meija (dalam Ilyas) bahwa faktor yang mempengaruhi kinerja terdiri dari faktor internal yaitu karakteristik individu seperti umur, pendapatan, masa kerja, pengalaman kerja dan status perkawinan, sikap terhadap tugas yang diberikan antara lain persepsi, pengetahuan, motivasi, tanggungjawab dan kebutuhan terhadap imbalan. Sedangkan faktor eksternal meliputi sosial ekonomi, demografi, lingkungan kerja, aseptabilitas, aksestabilitas, beban kerja, dan organisasi yang terdiri dari pembinaan, pengawasan, koordinasi dan fasilitas.

\section{Hubungan Tingkat Pengetahuan terhadap} Pengelolaan Obat

Dari hasil analisis yang didasarkan pada tabel IV, didapatkan nilai Correlation Coefficient sebesar 0,355 dan nilai $\mathrm{p}$ value sebesar 0,031. Menurut Sarwono (2014) untuk melakukan interpretasi korelasi menggunakan uji spearman yang dilihat adalah nilai
Correlation Coefficient untuk mengetahui kekuatan hubungan antara dua variabel Sarwono (2014) membaginya menjadi 6 kategori yaitu, jika nilai correlation coefficient senilai 0 maka tidak ada hubungan antara dua variabel, jika nilai correlation coefficient $>0-0,25$ korelasi sangat lemah, jika nilai correlation coefficient $>0,25-0,5$ korelasi cukup, jika nilai correlation coefficient >0,5-0,75 korelasi kuat, jika nilai correlation coefficient $>0,75-0,99$ korelasi sangat kuat, dan jika nilai correlation coefficient 1 korelasi sempurna. Nilai correlation coefficient yang didapat peneliti sebesar 0,355 yang artinya masuk dalam kriteria $>0,25-0,5$ yang artinya terdapat korelasi antara dua variabel dengan kekuatan cukup. Kemudian menurut Sarwono (2014) ada dua kategori untuk interpretasi arah dalam uji spearman. 2 kategori tersebut adalah jika koefisien korelasi positif maka hubungan kedua variabel searah, jika koefisien korelasi negatif maka hubungan kedua variabel tidak searah. Nilai koefisien korelasi yang didapatkan peneliti adalah positif $(+)$ 0,355 artinya terdapat 
hubungan searah antara 2 variabel yang menunjukkan jika tingkat pengetahuan tinggi maka kemampuan pengelolaan obat oleh pengelola unit farmasi juga tinggi.

Pengujian hipotesis dalam korelasi, peneliti membuat hipotesis hubungan antara variabel tingkat pengetahuan pengelola obat dengan pengelolaan obat yang dirumuskan sebagai berikut :Ho : Tidak ada hubungan antara tingkat pengetahuan pengelola unit farmasi dengan pengelolaan obat $\mathrm{Hi}$ : Ada hubungan antara tingkat pengetahuan pengelola unit farmasi dengan pengelolaan obat

Menurut Sarwono (2014) untuk melihat signifikansi hubungan kedua variabel melalui kriteria pengujian hipotesis langkah pertama yang harus dilakukan adalah dengan menggunakan nilai signifikansi hitung (sig o) < 0,05 maka $\mathrm{H}_{0}$ ditolak dan $\mathrm{H}_{\mathrm{i}}$ diterima, dan jika nilai (sig o) $>0,05$ maka $\mathrm{H}_{0}$ diterima dan $\mathrm{H}_{1}$ ditolak. Berdasarkan hasil penelitian didapatkan nilai signifikansi sebesar 0,031 sehingga didapatkan hasil 0,031<0,05. Ho ditolak dan $\mathrm{H}_{1}$ diterima yang artinya ada hubungan antara tingkat pengetahuan pengelola unit farmasi terhadap pengelolaan obat di Puskesmas.

Berdasarkan hasil penelitian di dapatkan ternyata ada hubungan antara tingkat pengetahuan pengelola obat dengan kemampuan pengelolaan obat yang bersifat searah artinya jika tingkat pengetahuan tinggi maka kemampuannya pun juga akan semakin baik. Menurut notoatmodjo 2007, pengetahuan yang dimiliki seseorang merupakan pemicu awal tingkah laku termasuk tingkah laku dalam bekerja pengetahuan sangat diperlukan dalam perubahan pola pikir dan perilaku.

\section{KESIMPULAN}

Dapat disimpulkan dari total 37 responden di dapatkan hasil bahwa 19 responden memiliki tingkat pengetahuan tinggi, 13 sedang dan 5 rendah. Sedangkan dalam pengelolaan obat sebanyak 21 responden memiliki pengelolaan obat sangat baik, 12 baik, dan 4 diantaranya kurang baik. Hasil Uji Statistik menunjukkan $p$ value sebesar 0,031 yang menunjukkan $0,031<0,05$ sehingga dapat disimpulkan bahwa Ada hubungan antara tingkat pengetahuan dengan pengelolaan obat di Puskesmas dan berdasarkan nilai Coefficient Correlation sebesar 0,355 menunjukkan kekuatan yang cukup dan searah antara Tingkat Pengetahuan Pengelola Unit Farmasi terhadap Pengelolaan Obat di Puskesmas wilayah Kabupaten Banyumas.

\section{DAFTAR PUSTAKA}

Azis, Sriana, (2006). Kemampuan Petugas Menggunakan Pedoman Evaluasi Pengelolaan dan Pembiayaan Obat Sebelum dan Sesudah Pelatihan, Majalah Kesehatan Masyarakat 72: 11-18: Jakarta

Bambang wahyudi, (2002). Manajemen Sumber Daya Manusia. Jakarta : Sulita

Budiarto, E., (2001). BIOSTATIKA untuk Kedokteran dan Kesehatan Masyarakat. Edisi 1., Jakarta : Buku Kedokteran EGC

Dinas Kesehatan Provinsi. (2014). Data Dasar Puskesmas Jawa Tengah. Jakarta : Kemenkes RI

Herman, MJ., Supardi, S., Yuniar, Y. (2013). Hubungan Ketersediaan Tenaga Kefarmasian dengan Karakteristik Puskesmas dan Praktik kefarmasian di Puskesmas : Badan Litbangkes. Kemkes RI

Ilyas, Yaslis. 2002. Kinerja. Teori, Penilaian dan Penelitian. Jakarta : Pusat kajian Ekonomi kesehatan FKM Universitas Indonesia. . 2004. Perencanaan Sumber Daya Manusia Rumah Sakit. T eori Metoda dan Formula. Jakarta: Pusat Kajian.

Katajavuori Nina, Hakkarainen Katja, (dkk). 2009. Curriculum Reform in Finnish Pharmacy Education. American Journal of Pharmaceutical Education. Volume 73. Num. 8. 2009. p.151-158.

Notoatmodjo 2007, Promosi kesehatan dan ilmu kesehatan, Rineka Cipta, Jakarta.

Anonim, 2006. Keputusan Menteri Perhubungan No. 51 tahun 2009 tentang Pemberian Izin Usaha Penyelenggaraan Sarana Perkeretaapian Umum kepada PT KCJ. Jakarta :Republik Indonesia

Sarwono, J. (2015). Rumus-Rumus Populer dalam SPSS 22 untuk Riset Skripsi. Edisi 1. Yogyakarta : C.V Andi Offset 
Sriana A, dkk, 2002. Kemampuan petugas menggunakan pedoman evaluasi pengelolaan dan pembiayaan obat .puslitbang farmasi dan obat tradisional, badan litbang kesehatan . majalah ilmu kefarmasian, Vol. II No.2 Agustus 2005.

Suryawati, S dan Annisa, E. (2001). Pengaruh Ketersediaan Dana Kontan Terhadap
Pengadaan dan Penggunaan Obat tingkat Puskesmas. Jurnal Manajemen Pelayanan Kesehatan Vol. 04/No.01/2001.

Wurjati, 2005. Gambaran Kinerja Petugas Pengelola Obat Puskesmas dan Faktor-Faktor yang Berhubungan di Kota Bekasi tahun 2004, http:digilib.ui.ac.id/opac/themes/libri2/de tail. 